\title{
ALTERNATIVE STRATEGIES IN THE USE OF INFORMATION TECHNOLOGY IN THE CONSTRUCTION INDUSTRY OF DIFFERENT COUNTRIES
}

\author{
S. K. Ting ${ }^{1}$ and F. Wang ${ }^{2}$ \\ Center for Advanced Construction Studies \\ School of Civil \& Structural Engineering \\ Nanyang Technological University
}

\begin{abstract}
The effective application of Information Technology (IT) in construction requires a combination of strategic and tactical development. This paper adopted a simplified strategic IT planning framework of four levels---national and government level, professional and institution level, construction enterprise level and construction project level to review the alternative strategies in the use of IT in the construction industry of different countries. Five representative countries, Singapore, Finland, United Kingdom, Japan and the United States are reviewed by their usage of IT in their construction industries. The objective of this study is to analyze how a proper management policy can contribute to effective IT applications for different countries under differing practices and conditions.
\end{abstract}

Keywords: Information Technology, Strategic IT, construction IT and Framework

\section{BACKGROUND}

The nature of business in all sectors has undergone accelerating change over recent years, especially after the emergence of the information revolution. Employing Information Technology (IT) may result in a number of competitive advantages.

The effective application of IT in construction requires a combination of strategic and tactical development. The strategic development focuses on the management policy while the tactical development focuses on the technology aspect. Much of the work in the research community has focused on tactical concerns relating to technology issues [1]. Researchers, software developers, and practitioners are now applying information technology in different stages of the construction process. Nowadays, the use of IT in construction is becoming increasingly sophisticated with the latest technological advances such as virtual reality, knowledge-based systems, object-oriented approaches and neural networks.

However, in response to the constant change in technology, regulations and market, the shift in emphasis of management from tactical to strategic is emerging. In terms of innovative IT, the emphasis is now moving from solely technological concerns to how technology can be managed and applied [2].

Amid the globalization of construction, nations, more specifically their construction industries, need to undertake strategic IT planning and devise IT strategies. On $16^{\text {th }}$ April 1997, Global Construction IT Futures International Meeting was held by the Innovative Manufacturing Initiative (IMI) in Salford University, UK. In this meeting, delegates from Australia, Finland, Hong Kong, Japan, Slovenia, South Africa, Sweden, UK and USA discussed the ongoing IT strategy initiatives in their construction industry, explored the way ahead for global construction IT and established a global research network for construction IT [3].

In this paper, the authors first introduced a four level framework of strategic IT in construction. This is a simplification of Betts' five level framework. Five countries were reviewed to show how strategic IT is implemented in practice at the different levels.

\footnotetext{
${ }^{1}$ Associate Professor and Director, Centre for Advanced Construction Studies, School of Civil \& Structural Engineering, Nanyang Technological University, Singapore; Email: CSKTING@,ntu.edu.sg

${ }^{2}$ Graduate Student, Division of Construction Technology and Management, School of Civil \& Structural Engineering, Nanyang Technological University, Singapore; Email: p147227135@ntu.edu.sg
} 


\section{ALTERNATIVE STRATEGY APPROACHES FOR IT APPLICATION}

\subsection{Strategic IT management in construction}

Earl [4] who looked at the management of IT from the strategic angle changed the current thinking on IT. For the construction industry, Betts and Ofori [5] suggested that IT offered opportunities as strategic weapons to gain competitive advantage, improve productivity and performance, enable new ways of managing and organizing, and develop new business opportunities. Therefore, various organizations in different countries have been putting in efforts to introduce strategic planning for IT applications in their construction industry.

\subsection{Five-level frame work of IT application}

Since construction is a very diversified industry, it is necessary to analyze the application of strategic planning and management by several levels. Betts [2] developed the concept of strategic IT, made by Earl [4] and Porter and Millar [6]. He provided a five level framework for strategic application of IT in construction, as shown in Table 1.

Table 1 Five levels of Strategic IT in Construction

\begin{tabular}{|c|l|l|}
\hline Levels & \multicolumn{1}{|c|}{ Application } & \multicolumn{1}{|c|}{$\begin{array}{c}\text { Responsibility for } \\
\text { implementation }\end{array}$} \\
\hline Level 1 & $\begin{array}{l}\text { National construction } \\
\text { industry }\end{array}$ & Public-sector agencies \\
\hline Level 2 & Professional institution & $\begin{array}{l}\text { Professional bodies } \\
\text { and trade association }\end{array}$ \\
\hline Level 3 & Construction enterprise & Enterprise \\
\hline Level 4 & Construction project & Client and project team \\
\hline Level 5 & Construction product & Client and project team \\
\hline
\end{tabular}

Source: Betts (1999) [2]

In this paper, we selected the first four levels to review the alternative strategies in the use of IT in the construction industry in different countries.

\section{National Level}

Under the pressure of global competition in construction, many nations and their construction industries adopt strategies through their public agencies. It is the government-led, industry-wide effort in IT application. At this level, information is potentially shared and communicated extensively, across professional boundaries and throughout the construction process. Any IT development at this level would require the understanding, participation and support of all professions, enterprises and government agencies [2]. For instance, in Japan, the Information Network System is a national plan for an IT network [7]. In the United States, the Computer Integrated Construction has also received attention of the National Bureau of Standards [8]. The most significant national IT strategic planning is the CORENET project in Singapore and the VERA program in Finland.

\section{Professional and Institution Level}

Professional level implementation is the responsibility of institutions. In order to gain interprofessional advantages, the professional bodies are taking steps to accelerate and implement IT applications. At this level, information is shared and systems are developed for all subscribing members of a professional body for their own benefit.

\section{Enterprise Level}

The most significant and common examples of current strategic IT planning in construction occur at this level [9]. Facing the dynamic market environment, information technology (IT) is no longer just word processing in the head office. It is rather regarded as a long-term development strategy for both large international enterprise and companies of medium and small sizes. Strategic IT management is regarded as a vital part to improve both internal and external competitiveness.

\section{Project Level}

In contrast to the business and manufacturing industries, the fundamental operating level of construction is the project. This level concentrates on clients' demand and IT capacity according to the project situation. Based on the client's demand and project specification, the IT implementation strategy will adjust accordingly, taking into consideration potential advantages.

In the next part of this paper, we review how other countries adopt these four levels of strategic IT in practice.

\section{IMPLEMENTING IT STRATEGY IN PRACTICE}

\subsection{Singapore National Initiative on Construction IT}

The National IT Plan (NITP) was launched in Singapore in 1986. It provided a blueprint for an action program that called for the exploitation of IT to develop a strong export oriented economy. 
The NITP has seven interactive building blocks, namely IT industry, IT manpower, information communication infrastructure, IT application, coordination and collaboration, IT culture and climate for creativity and enterprise [2].

The construction industry is under the IT application program, for which three strategies were developed:

- Build up an extensive information infrastructure to enhance the usefulness of IT,

- Promote IT as a means to increase productivity and business competitiveness, and

- Extend the public sector computerization programs to encompass users in private sectors.

CORENET, which stands for the Construction and Real Estate NETwork, is a major initiative implemented by the Singapore Ministry of National Development (MND). It was launched in 1991 and aimed at increasing the productivity and efficiency for the whole construction industry, from conceptual design to facilities management in a building life cycle [10]. It is a very delicate and complicated network infrastructure, including four main systems.

- Collaborative Design System - It uses IT systems to facilitate communication and workflow refinement among members. It provides the environment that allows developers, consultants and key industry players in different locations to communicate and work together as though they are physically together.

- Procurement System - It provides a business to business (B2B) environment where developers, consultants, constructors, suppliers and other key players in the construction industry can transact and procure products and services electronically. The Singapore Contractors' Association Ltd (SCAL) launched this EProcurement project in October 1999.

- Construction Systems - It uses IT systems to facilitate building processes and project management. This helps project managers, consultants and contractors to monitor and manage their projects effectively.

- Facilities Management Systems - It is used to facilitate assets management, building performance and property maintenance.

Due to the small size of corporate enterprises and the strength of the central agencies, nation-wide construction IT initiative is accepted as a more appropriate approach to Singapore.

\subsection{Finland National Construction IT program}

Finland, a small but knowledge orientated developed country, has a long tradition of interest and expertise in construction IT research which gains a lead reputation in the technology [2].

Like CORENET in Singapore, VERAInformation Networking in the Construction Process, is a national program of Finland [11]. Tekes, the National Technology Agency of Finland, developed VERA. It was launched in August 1997 and planed to last six years. The overall budget for this program was 170 million Finnish marks (US\$ 34 million), about $20 \%$ of funding was for applied technical research (public projects) and $80 \%$ for industrial R\&D projects.

The purpose of Vera is to promote the utilization of product information technology and information networks in construction processes, and to make it possible to manage the construction information flows during the entire life cycle of the building [11].

There are five main themes of Vera (Figure 1), which involve the main strategic thought of IT application - coordination between various parties in construction business and integration through the whole construction life cycle. Under this National technology program, there are several research projects (for more information, please refer to http://cic.vtt.fi/vera/english.htm).

The strategic effect of such nation-led, industry-wide approaches is the most beneficial and broadest level at which IT strategy can be applied. It also improves external competitiveness of the industry as a whole. Recently, government-led integrated construction IT program has been very successful in helping Finland to obtain and maintain high productivity in construction projects [12].

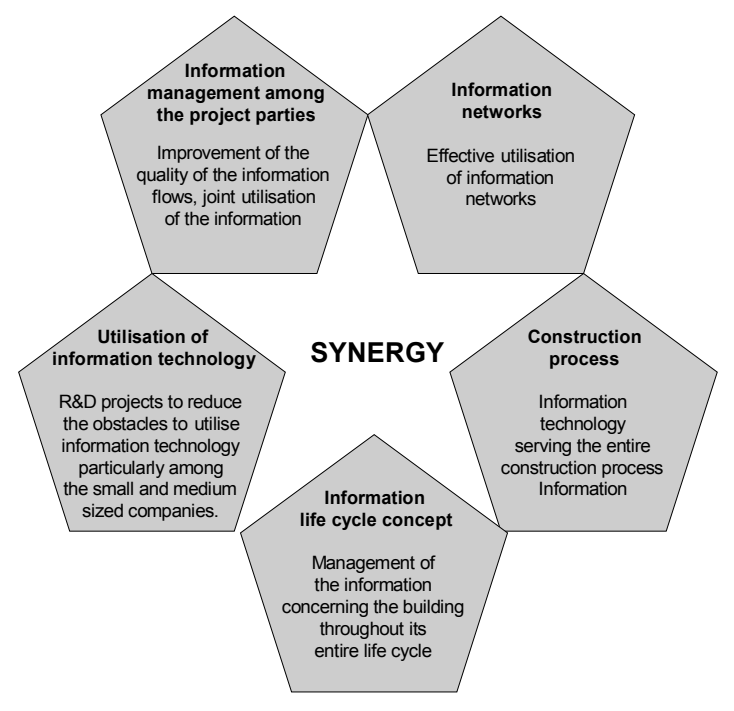

Figure 1 Five Main Themes of VERA

\subsection{UK Construction IT initiative}


Responding to the Latham review of the UK construction industry and the more recent Egan report (1998), the idea of national construction strategy IT is being considered in the UK by groups such as the Construction Industry Board (CIB) and the Construction Research and Innovation Strategy Panel (CRISP) [2].

The Construct IT Center of Excellence in the UK is an industry-led, government-endorsed network, which involves more than 70 leading companies, institutions and universities [13]. With the aim of developing construction industry process strategy, the center performs benchmark analyses, carries out pilot innovation projects and encourages discussion among members.

Allies of the Construct IT Center include [14]:

- Building Research Establishment (BRE) Technology Expertise/National Strategy

- Construction Industry Computing Association (CICA) - Technology Transfer

- Construction Industry Council (CII) - interProfessional Integration

- Department of the Environment (DETR) Government standard/National Strategy

- EDICON - Existing Collaborative Efforts and Experience

- CIBSE, CIOB, ICE, RIBA and RICS - Major Interest Groups

- University of Salford-Research, Education and Technological Expertise

These organizations as parts of Construct IT Center are independent in terms of their projects, innovations, products and services. Meanwhile, they share a common vision of the need for coordinated action, contribute their individual activities to the Center and combine to undertake joint activities.

Such professional institutions influence UK construction industries in a very significant way. They are taking the responsibility to lead and implement the strategic use of IT.

\subsection{Enterprise-Led Construction IT in Japan}

In Japan, the construction industry is dominated by super general constructors of which the five big companies are: Taisei, Shimizu, Kajima, Obayashi and Takenaka with 10,000 to 14,000 employees each and which service more than $60 \%$ of the construction contracts [15]. These general contractors have a large number of engineering staffs specialized in $R \& D$ projects.

Although the Ministry of Construction set up the CI-NET (Construction Industry Information Network) center in 1992, which is responsible for the standardized data exchange [16], the main research work and practical realization are led by the big enterprises in Japan.
Recently, much of the effort in IT implementation were carried forth in the context of Computer Integrated Construction (CIC), in which advanced information and automation technologies are effectively utilized in the construction industry [17]. For example, Shimizu structured systematic models toward implementing CIC: (1) integrated design/construction planning, (2) factory automation system, (3) site automation system, and (4) multi-project management system with central project database.

Such strategic use of IT is leading to improvements in the productivity and competitiveness of the individual enterprise and, because of their dominating status in the industry; the overall competitiveness of the industry is improved as well.

\subsection{Project Oriented Construction IT in US}

Due to a highly competitive industrial environment, many US construction companies such as the Bechtel Group Inc, M.W. Kellogg Corp and Foster Wheeler Corp., etc., view information technology as their vital competitive advantage. For example, Bechtel was considering the use of Internet technologies to transmit virtual-reality $3 \mathrm{D}$ images to clients in different country [18]. Also, M.W. Kellogg Corp. had stated that they were to complete their computer systems to a high state of integration to gain efficiency as a part of a dual service and cost leadership strategy [2].

Compared with Japan, however, big construction companies in US are not as dominating, for multiple competition and market sharing exist. However, in terms of information technology application, the construction industry is greatly effected by the IT industry in US.

The US has the greatest concentration of producers and users of IT systems [19]. Many US hardware and software vendors are also recognized as being innovative world leaders in the development of IT systems due to their huge R\&D capability. The examples include Autodesk Company's effort in 3D and 4D modeling in CAD, Sun Microsystems' 'Java' in Internet-based integration and the Primavera Company's P3 for project management. [17].

Under this interdisciplinary situation, most construction companies implement their strategic IT based on the project alone. According to the requirement of client, the actual situation of the project and the capability of project team, they chose a tailor-made IT system and strategic implementation for construction process control. 


\section{THE WAY FORWARD}

This paper reviews each of the countries on the level in which their strategic IT applications are the most effective, inconclusive of the environment. Different countries have alternative approaches to the application of IT. From the discussion, we have seen a number of areas in which the construction sectors are being strategic in its IT use. However, the current use of IT for strategic purposes in construction is still rather limited. And more effort should be put in to make it more widespread in our industry to achieve higher productivity and more benefits. In this respect, the professional bodies and government agencies may play important roles in overall coordination, development and maintenance.

\section{Acknowledgments}

The authors wish to express their sincere gratitude to the Singapore's Building and Construction Authority (BCA) for providing and explaining the actual implementation of Construction IT in Singapore.

\section{REFERENCES}

[1] Betts, M. "Technology Planning Frameworks to Guide National IT Policy in Construction", Automation in Construction, 6, pp. 251-266, 1995.

[2] Betts, M. Strategic Management of I.T. in Construction, Blackwell Science, 1999.

[3] Global Construction IT Network http://cic.vtt.fi/links/constrit.html

[4] Earl, M J. Management Strategies for Information technology, Prientice-Hall, London, 1989.

[5] Betts, M. and Ofori, G. "Strategic Planning for Competitive Advantage in Construction: the Institutions", Construction Management and Economics, 12, pp. 203-217, 1994.

[6] Porter, M E. and Millar, V E. "How Information Gives You Competitive Advantage", Harvard Business Review, July-August, pp. 79-91, 1985.

[7] Hasegawa, F. Built by Japan: Competitive Strategies of the Japanese Construction Industry, John Wiley \& Sons, N.Y., 1988.
[8] Wright, R N. “Computer Integrated Construction", Periodical, International Association for Bridge and Structure Engineering, 1, February, pp. 17-24, 1988.

[9] Betts, M. "How Strategic is Our Use of Information Technolosgy in the Constuction Sector?" Internation Journal of Information Technology in Construction, No. 1, 1992.

[10] CORENET, Singapore, http://www.corenet.gov.sg/Corenet/index.html

[11] VERA, Finland, http://cic.vtt.fi/vera/english.htm

[12] VTT "VTT Building Technology Annual Review”, VTT, Finland, 1998 http://cic.vtt.fi/links

[13] Topping, G. "The UK Construct IT Center of Excellence", Presentation on Construct IT Center of Excellence, 1999. http://www.construct-it.salford.ac.uk/,

[14] Betts, M. and Brandon, P. "National Collaboration for Integrated Construction IT", Paper on Global Construction IT Futures International Meeting, 1997.

http://www.surveying.salford.ac.uk/meeting/docs /abstarcts.htm

[15] Suzuki, A. "Present Status and Prospects of Construction Control Systems in Japan", Proceeding of the Sixth International Conference (V-ICCCBE) July 12-15, Vol. 1 pp. 39-48, 1995.

[16] Japan CI-NET, kikin.or.jp/ci-net/eng/index.html 
[17] Yamazaki, Y., "Computer Integrated Construction" Journal of the International Association for Bridge and Structural Engineering, February, pp. 17-24. 1995.

[18] Hansen, K L ～Gann, D M. ～\& Groak, S. "Information Technology Decision Support and Business Process Change in the USA", Engineering Construction and Architectural Management 5/2, pp. 115-126, 1998.

[19] European Commission Panorama of EU Industry 95-96, European Communities Publication, Luxembourg, 1995 
